\title{
The German Reception of Geoffrey of Monmouth
}

\author{
Joshua Byron Smith
}

Geoffrey's German reception appears meagre in light of what we might expect. ${ }^{1}$ No vernacular translation exists, and the number of manuscripts connected to German libraries is comparatively small, with only seven in Crick's Summary Catalogue. ${ }^{2}$ Of course, Arthurian literature was popular in German-speaking lands, but, with very few exceptions, the intermediary sources seem to have been French. Indeed, one reads with regularity statements like the following: "There is little reason to doubt that the German authors who introduced Arthurian romance in southern Germany in the years around 1200 were indeed working from French sources."3 However, two somewhat recent studies have suggested that Geoffrey's Latin works did have an influence, however small, on popular German literature. Hartmann von Aue might have used Geoffrey's $D G B$ as a source for some of the names in Erek, though the poor textual transmission of this important work makes it difficult to say anything with certainty. ${ }^{4}$ Another vernacular work that might betray Geoffrey's influence is Wirnt von Grafenberg's Wigalois. Wigalois contains a full-on military expedition and siege, matters which are usually not present in Arthurian romance, but a recent study has attempted to rehabilitate this narrative "defect" by arguing that Wirnt took inspiration from the $D G B$ 's description of King Arthur's military campaign against Rome. ${ }^{5}$ Both studies acknowledge the tension between Geoffrey's wider popularity and his lack of overt influence on vernacular German literature: "Although there are no marked intertextual references to Geoffrey's work in German-language Arthurian romances, the

1 My sincere thanks to Joseph M. Sullivan for providing references to me and for general advice on this article.

2 See Crick, $S C$, nos. 15, 56, 75, 183, 205, 213, 216. An abridgement is also present in Berlin, Staatsbibliothek, Phillipps 188o; see Crick, SC, p. 33o. See also Jaakko Tahkokallio's chapter in this volume.

3 W.H. Jackson and S.A. Ranawake, "Introduction", in W.H. Jackson and S.A. Ranawake (eds.), The Arthur of the Germans: The Arthurian Legend in Medieval German and Dutch Literature (Arthurian Literature in the Middle Ages, 3), Cardiff, 20oo, pp. 1-18, at p. 4.

4 C.J. Steppich, “Geoffrey's 'Historia Regum Britanniae' and Wace's 'Brut': Secondary Sources for Hartmann's 'Erec'?" Monatshefte 94 (2002), 165-88.

5 R. Brockwyt, "Ein Artusritter im Krieg. Überlegungen zur Namûr-Episode im Wigalois des Wirnt von Grafenberg aus intertextueller Perspektive", Neophilologus 94 (2010), 93-108. 
breadth and scope of the distribution of his manuscripts in German-speaking territory could speak to a high degree of familiarity, among the literati at least." ${ }^{6}$ In this regard, the German reception mirrors the Dutch: Geoffrey's Latin history, though available, did not excite the minds of German romance writers. Moreover, no known manuscript of Geoffrey's $P M$ currently resides in a German archive, which seems to reflect a lack of medieval interest in the text. Indeed, while the $P M$ was popular elsewhere in Europe, especially in those areas under Norman influence, German speakers paid them little heed, and the most complete survey of later medieval prophetic writing in the High German regions does not even mention Geoffrey's name. ${ }^{7}$ In sum, Geoffrey's popularity waned east of the Rhine. Perceptive readers of this article will note its small size and the fact that one of the editors - who is not a Germanicist has written it, which suggests that more work needs to be done on Geoffrey's German reception, if only to speculate on reasons why German readers chose not to take inspiration from him.

6 Brockwyt, "Ein Artusritter im Krieg”, p. 98, n. 23: "Obwohl es keine markierten intertextuellen Bezüge in den deutschsprachigen Artusromanen auf Geoffreys Werk gibt, könnte die Weite und Dichte seiner handschriftlichen Verbreitung auch im deutschsprachigen Raum für einen hohen Bekanntheitsgrad zumindest unter den litterati sprechen."

7 F.C. Kneupper, The Empire at the Edge of Time: Identity and Reform in Late Medieval German Prophecy, Oxford, 2016. I would like to thank Frances Courtney Kneupper for confirming that Geoffrey's $P M$, and prophecies attributed to Merlin in general, was not as popular in medieval Germany as in other parts of Europe. See ch. 24 for Frederick II and Merlin. 